\title{
A QUASI-EXPERIMENTAL STUDY TO ASSESS THE EFFECTIVENESS OF STRUCTURED TEACHING PROGRAMME ON KNOWLEDGE REGARDING EPILEPSY AND ITS FIRST AID MANAGEMENT AMONG B.ED. STUDENTS AT SELECTED B.ED. COLLEGE IN JAIPUR
}

\author{
MR. PIYUSH BHARDWAJ' ${ }^{1}$ MR. HITESH GAUTAM ${ }^{2}$ \\ ${ }^{1}$ Assistant Professor, Nursing Lecturer Liberty College of Nursing, Jaipur \\ ${ }^{2}$ Principal GL Saini College of Nursing, Jaipur
}

Corresponding Email: piyushbhardwaj2307@gmail.com

\begin{abstract}
:
Introduction: A thought, idea or mental image concept is framed in the mind in response to learning something new. A framework work is basic structure supporting anything. A conceptual frame work deals with abstraction that is assembled by nature of their relevance to common theme. Inter related concepts or abstraction that is assembled together in some rational scheme by virtue of their relevance to a common theme; they serve as a spring board for generation of hypothesis to be tested.

Material and Method: This study was conducted in Jaipur Rajasthan. Study comprised of Sample size of total 60 B.Ed. students studying in Sneh Teacher's Training College, Muhana, Sanganer, Jaipur. Nonprobability purposive sampling technique was used to select $60 \mathrm{~B}$.Ed. students. The research design was quasi - experimental two group pre-test post-test design.

Result: Analysis in an appraisal of the data and interpretation of the inferences that emerge from the study findings. The data collected from 6 O B.Ed. students was analyzed, classified and tabulated on the basis of the objectives of the study. The results were presented by frequency, percentage, mean, standard deviation, correlation co-efficient and chi-square.
\end{abstract}

Conclusion-it is concluded that the level of knowledge regarding epilepsy and its first aid management among B.Ed. students was inadequate. Therefore, the knowledge of the B.Ed. students can be further improved by providing structured teaching programme.

Keyword: assess, educational modules health problems'. students regarding epilepsy and its first aid management.

\begin{tabular}{ccc}
\hline Received & Accepted & Available online \\
\hline $31 / 07 / 2021$ & $04 / 08 / 2021$ & $05 / 08 / 2021$ \\
\hline
\end{tabular}




\section{INTRODUCTION}

"Epilepsy is a part of your life, not whole life"Children are the assets of our country. Diseases of the nervous system are fairly common in pediatric practice. Almost 20-30 percent of

children encounter acute, chronic or recurrent neurological illnesses. These are major contributors to childhood morbidity and disability.Epilepsy has been defined as "a neurological condition characterized by recurrent, unprovoked, and paroxysmal episodes of brain dysfunction manifesting as a large number of clinical phenomena like altered levels of consciousness, involuntary movements, abnormal sensory phenomena, autonomic changes and transient disturbance of behavior. It is also referred as the seizure disorder.Epilepsy is one of the most prevalent neurological conditions and it knows no age, racial, social class, geographic, or national boundaries. The impact of epilepsy rests not only on the individual patient, but also on the family and indirectly on the community.

\section{MATERIAL AND METHOD}

A quasi - experimental design approach was adopted to assess the regarding epilepsy and its first aid management in among B.Ed. students' knowledge and skills in identification of epilepsy problems in children on the basis of teachinglearning methods for children (Teacher's Scale) The following steps were followed.

\section{Step I}

IN EXPERIMENTAL GROUP AND CONTROL GROUP.

Assess the level of knowledge on epilepsy and its first aid management

Step II: Administrated Structured Educational Modules [SEM]: Structured teaching plus SIM for Group I and SelfInstructional Module only for Group II and no intervention for Control Group.

Step III: Post assessment was done on Knowledge and skills in identification epilepsy and its first aid management by administering the same tools to Group I, Group II and Control Group.

\section{RESULT: DISTRIBUTION OF DEMOGRAPHIC VARIABLES}

Table no. 1: Description of pre-test level of knowledge regarding epilepsy and its first aid management in experimental and control groups

\begin{tabular}{|c|c|c|c|c|c|}
\hline \multirow{2}{*}{ S. No } & $\begin{array}{c}\text { Level Of } \\
\text { Knowledge }\end{array}$ & \multicolumn{2}{|c|}{$\begin{array}{c}\text { Experimental } \\
\text { Group } \\
(\mathbf{n = 3 0})\end{array}$} & \multicolumn{2}{c|}{$\begin{array}{c}\text { Control Group } \\
(\mathbf{n = 3 0})\end{array}$} \\
\cline { 3 - 6 } & $\mathrm{F}$ & $\%$ & $\mathrm{~F}$ & $\%$ \\
\hline 1 & Poor ( $\leq 50 \%)$ & 20 & $66.66 \%$ & 22 & $73.33 \%$ \\
\hline 2 & $\begin{array}{c}\text { Average (51- } \\
65 \%)\end{array}$ & 05 & $16.66 \%$ & 05 & $16.66 \%$ \\
\hline 3 & Good (>65\%) & 05 & $16.66 \%$ & 03 & $10 \%$ \\
\hline
\end{tabular}

The table no. 01 showed the distribution of PreTest level of knowledge among experimental and control group. With regard to scores, in the experimental group during pretest, 20 (66.66\%)

GFNPSS-International Journal of Multidisciplinary Research, Volume 2, Issue 7, July 2021

DOI: 10.46376/IJMR/2.7.2021, P a g e 726 | 32 
B.Ed. students had poor knowledge, 05 (16.66\%)

of them had average knowledge and 05 (16.66\%) had good knowledge regarding epilepsy and its first aid management.

In the control group, during pre-test, 22 (73.33\%) B.Ed. students had poor knowledge, 05 (16.66\%) of them had average knowledge and 03 (10\%) of them had good knowledge regarding epilepsy and its first aid management.

Table No. 02: Mean, Mean Percentage, Standard Deviation, Standard Deviation Percentage Of Pre-Test Level Of Knowledge Regarding epilepsy and its first aid management In Experimental And Control Groups

\begin{tabular}{|c|c|c|c|c|c|}
\hline $\begin{array}{c}\text { S. } \\
\text { No }\end{array}$ & Group & Mean & $\begin{array}{c}\text { Mean } \\
\mathbf{\%}\end{array}$ & SD & SD\% \\
\hline 1 & $\begin{array}{c}\text { Experimental } \\
\text { Group } \\
(\mathrm{n}=30)\end{array}$ & 13 & $43.33 \%$ & 1.06 & $3.53 \%$ \\
\hline 2 & $\begin{array}{c}\text { Control Group } \\
(\mathrm{n}=30)\end{array}$ & 12.5 & $41.67 \%$ & 1.25 & $4.16 \%$ \\
\hline
\end{tabular}

The table no. 02 shows that the Mean pre-test knowledge score was 13, Mean percentage was 43.33\%, Standard Deviation was 1.06 and the Standard Deviation percentage was $3.53 \%$ regarding epilepsy and its first aid management in experimental group.

In the control group the Mean pre-test knowledge score was 12.5 , Mean percentage was $41.67 \%$, Standard Deviation was 1.25 and the Standard
Deviation percentage was $4.16 \%$ regarding epilepsy and its first aid management in experimental group.

Table No.03: Analysis Of The Level Of Knowledge Before And After Administration Of STP Regarding epilepsy and its first aid management In Experimental Group

\begin{tabular}{|c|c|c|c|c|c|}
\hline $\begin{array}{c}\text { S. } \\
\text { No }\end{array}$ & $\begin{array}{c}\text { Experiment } \\
\text { al group }\end{array}$ & $\begin{array}{c}\text { Mea } \\
\mathbf{n}\end{array}$ & $\begin{array}{c}\text { Mean } \\
\text { differen } \\
\text { ce }\end{array}$ & $\begin{array}{c}\text { d } \\
\text { f }\end{array}$ & $\begin{array}{c}\text { Calculat } \\
\text { ed value }\end{array}$ \\
\hline & Pre Test & 13 & 11.7 & 2 & 45.19 \\
\cline { 1 - 2 } & Post Test & 24.7 & & 9 & \\
\hline
\end{tabular}

Table No. 03 is showing that in experimental group the mean of pre test is 13 , mean of posttest is 24.7 with mean difference is 11.7. In the experimental group the calculated value of ' $\mathrm{t}$ ' is 45.19 at $29 \mathrm{df}$ at 0.05 level of significance .

Table No. 04: Analysis of The Level Of Knowledge Before And After Administration Of STP regarding epilepsy and its first aid management In Control Group

\begin{tabular}{|r|l|c|c|c|c|}
\hline $\begin{array}{r}\text { S. } \\
\text { No. }\end{array}$ & $\begin{array}{c}\text { Contro } \\
\text { I group }\end{array}$ & $\begin{array}{c}\text { Mea } \\
\mathbf{n}\end{array}$ & $\begin{array}{c}\text { Mean } \\
\text { differenc } \\
\text { e }\end{array}$ & Df & $\begin{array}{c}\text { Calculate } \\
\text { d value }\end{array}$ \\
\hline 1 & Pre Test & 12.5 & 0.5 & 29 & 1.744 \\
\hline 2 & $\begin{array}{l}\text { Post } \\
\text { Test }\end{array}$ & 13 & & & \\
\hline
\end{tabular}


Table no. 04 showing that in control group the mean of pre-test is 12.5, mean of post-test is 13 with mean difference is $\mathbf{0 . 5}$. in control group the calculated value of ' $t$ ' is 1.744 at $29 \mathrm{df}$ at 0.05 level of significance

DISCUSSION: The findings of the study are discussed under the following categories. The discussion is based on demographic variables of the subjects, objectives, hypothesis, related literature and conceptual frame work of the study and findings are discussed by comparing the findings of studies already undertaken in this area.

CONCLUSION: From the findings of the present study, it is concluded that the level of knowledge regarding epilepsy and its first aid management among B.Ed. students was inadequate. Therefore the knowledge of the B.Ed. students can be further improved by providing structured teaching programme.

\section{REFERENCES:}

1. Polit and Hungler (1977),'Nursing Research Principles \& methods', Philadelphia J.B. Lippincott.

2. Dorothy R Marlow. Barbara A Redding. Text book of pediatric nursing $1 \mathrm{st}$ edition.2007. W.B. Sounders Company page no. 957-958.

3. Sharma Suresh, Nursing Research and statistics; Elsevier, New Delhi,2012, p no. $70-71$.

4. Michael Swash. Hutchison's clinical methods. 21st ed. London: Saunders publications.2002.p.273-274.

5. Porter R.J. Epilepsy. "100 elementary principles". Philadelphia. W.B.Saunders Company. 1984.PP no.46-58 